\title{
From Historical Structures to Temporal Layers : Hans Freyer and Conceptual History
}

\section{Pankakoski, Timo Juhani}

2020-03-18

Pankakoski , T J 2020 , ' From Historical Structures to Temporal Layers : Hans Freyer and Conceptual History ' , History and Theory , vol. 59 , no. 1, pp. 61-91 . https://doi.org/10.1111/hith.12146

http://hdl.handle.net/10138/317768

https://doi.org/10.1111/hith.12146

Downloaded from Helda, University of Helsinki institutional repository.

This is an electronic reprint of the original article.

This reprint may differ from the original in pagination and typographic detail.

Please cite the original version. 


\title{
From Historical Structures to Temporal Layers: Hans Freyer and Conceptual History
}

Timo Pankakoski

Centre for European Studies, University of Helsinki, Finland

[Pre-print version - forthcoming in History and Theory 59:1, 2020]

\begin{abstract}
The article assesses, for the first time, the significance of the sociologist, philosopher, and conservative political theorist Hans Freyer for German conceptual history. Freyer theorized historical structures as products of political activity, emphasized the presence of several historical layers in each moment, and underscored the need to read concepts with regard to accumulated structures. He thus gave significant impulses not only to German structural history but also to conceptual history emerging out of it in the work of Otto Brunner, Werner Conze, and, most notably, Reinhart Koselleck, whose theories of temporal layers in history and concepts reworked the Freyerian starting points. Underscoring the openness and plurality of history, criticizing its false "plannability," and reading world history as European history writ large, Freyer shaped the politically oriented theory of history behind Koselleckian Begriffsgeschichte. Further, Freyer theorized the eighteenth- and nineteenth-century transition to the industrial society as a historical rupture or "epochal threshold", which bears close, and by no means coincidental, similarity to Koselleck's saddle time thesis. Freyer's theory of history sheds light on the interrelations of many Koselleckian key ideas, including temporal layers, the contemporaneousness of the non-contemporaneous, the plannability of history, and the saddle time.
\end{abstract}

\section{Keywords}

Hans Freyer, Reinhart Koselleck, conceptual history, social history, philosophy of history, conservatism, Otto Brunner, Werner Conze

\section{Introduction}

Rather than being a mere set of practices, German conceptual history carries an embedded theory of history and modernity. This is arguably both its strength and a potential source of restraints, possibly hindering its generalizability beyond European spaces. Begriffsgeschichte arose at a particular juncture in European history, the dynamics of which the theorists sought to comprehend by engaging with modern political and social concepts. To understand its current forms, we must dig into the historical layers upon which Begriffsgeschichte stands. The present article is a part of such a continued endeavor. It engages with the work of the German conservative sociologist, historian, and philosopher Hans Freyer (1887--1969) and maps his role in the genesis of German conceptual history, proposing significant parallels and direct historical links. The essay starts by discussing the social historians Otto Brunner (1898-1982) and Werner Conze (1910--1986) and then turns to Reinhart Koselleck (1923--2006), the most central theorist of the methodology of Begriffsgeschichte.

My key claim is that Freyer, in a complex, cumulative, and collective process of reception, provided significant impulses not only to German structural history but also to the history of concepts that emerged out of it. Freyerian themes were filtered into Koselleck's theories partly through his seniors, partly in direct engagement with Freyer's thought. We comprehend 
many of Koselleck's methodological categories, such as "time layers," "contemporaneousness of the non-contemporaneous," "saddle time," or the plurality of history, in more nuance when we read them against the background of Freyer's historical theory. This also helps better us conceive the interrelations between these notions, the metaphorical imagery guiding Koselleck's use of them, and the politically oriented theory of history underlying the whole edifice.

Freyer began his career with expressionistic essays and Hegelian cultural philosophy. ${ }^{1}$ In the late Weimar period, he theorized the foundations of the new discipline of sociology in Leipzig, framing sociology as the methodologically sound analysis of social reality in historical categories. ${ }^{2}$ In his concurring radical phase, Freyer theorized the state in ostensibly Hegelian categories, anticipated what he called "a revolution from the Right," and celebrated the state's ability to wage wars in the name of the Volk, first supporting the Nazi regime, but gradually growing more critical of its doctrines. ${ }^{3}$ During and after the Second World War, Freyer deradicalized ${ }^{4}$ his ardent nationalism into general reflections of Europe's historical significance in world history and the Western cultural heritage in general - thereby turning from the active call for revolutionary deeds into culturally conservative observations of historical phenomena on the global scale. ${ }^{5}$ Nevertheless, the motivating force behind Weltgeschichte Europas, written during the war but published in 1948, was to comprehend the novel ideological division of the world in widest historical categories - and thereby also indirectly relativize the recent German war effort into a minor incident in global history. In Theorie des gegenwärtigen Zeitalters (1955) and Schwelle der Zeiten (1965), Freyer criticized modern mass societies from a moderate anthropological perspective, now toning down his radicalism in favor of "traditional" conservatism primarily concerned with the fate of culture, individuality, and meaning in the modern "industrial societies." He suggested historical traditions and cultural heritage as counter-measures to modern rootlessness and theorized the transition to the industrial societies as a major anthropological shift in human history, gaining wide popularity in the postwar West Germany. ${ }^{6}$ Despite the changes, there are also significant continuities between Freyer's prewar and postwar work, and his ideas found resonance amongst those in need of alternative cultural explanations for the post-WW2 predicament, those resisting too rapid "Westernization," and those struggling with their own dubious past.

Freyer's thought, however, also shaped academic historiography. Scholars have noted Freyer's influence on German social history as exercised particularly by Brunner and Conze. Kaminsky and Van Horn Melton note how the origins of Brunner's historical thought laid "in the antiliberal thinking of pre-Nazi Weimar intellectuals like Carl Schmitt and Hans Freyer."7 In Veit-Brause's formulation, Conze "responded favorably to [Freyer's] ... historically

\footnotetext{
${ }^{1}$ Hans Freyer, Antäus: Grundlegung einer Ethik des bewussten Lebens (Jena: Diederichs, 1922[1918]); Hans Freyer, Prometheus: Ideen zur Philosophie der Kultur (Jena: Diederichs, 1923); Hans Freyer, Theorie des objektiven Geistes: Eine Einleitung in die Kulturphilosophie (Leipzig: Teubner, 1934[1923]).

${ }^{2}$ Hans Freyer, Soziologie als Wirklichkeitswissenschaft: Logische Grundlegung des Systems der Soziologie (Leipzig: Teubner, 1930); Hans Freyer, Einleitung in die Soziologie (Leipzig: Quelle \& Meyer, 1931).

${ }^{3}$ Hans Freyer, Der Staat (Leipzig: Rechfelden, 1925); Hans Freyer, Revolution von Rechts (Jena: Diederichs, 1931); Hans Freyer, Pallas Athene: Ethik des politischen Volkes (Jena: Diederichs, 1935); Hans Freyer, Die Politische Insel: Eine Geschichte der Utopien von Platon bis zur Gegenwart (Wien: Karolinger, 2000[1936]).

${ }^{4}$ On Freyer's shift, see particularly Jerry Z. Muller, The Other God that Failed: Hans Freyer and the Deradicalization of German Conservatism (Princeton: Princeton University Press, 1987).

${ }^{5}$ Hans Freyer, Weltgeschichte Europas, 2 volumes (Wiesbaden: Dieterich, 1948).

${ }^{6}$ Hans Freyer, Theorie des gegenwärtigen Zeitalters (Stuttgart: Deutsche Verlags-Anstalt, 1955); Hans Freyer, Schwelle der Zeiten: Beiträge zur Soziologie der Kultur (Stuttgart: Deutsche Verlags-Anstalt, 1965).

${ }^{7}$ Howard Kaminsky \& James Van Horn Melton, "Translators' Introduction," in Otto Brunner, Land and Lordship: Structures of Governance in Medieval Austria, trans. Howard Kaminsky and James Van Horn Melton (Philadelphia: University of Pennsylvania Press, 1992), xli.
} 
minded sociological theory." ${ }^{8}$ Thomas Etzemüller considers Freyer's influence on Conze as "clearly perceptible," while Jan Eike Dunkhause sees Freyer as "doubtless the contemporary thinker that had the greatest influence on Conze during the post-war years." Jin-Sung Chun concludes that Freyer was a crucial link between prewar radical conservatism and postwar structural history ${ }^{10}$, while Jerry Z. Muller remarks that the turn toward social history in Germany was "Freyer's greatest influence within the academy" and that Conze was "the most direct link between Freyer and the new social history." "1

The observation of Freyer's centrality for social history has become common currency, but scholars have so far overlooked how Freyer's ideas also guided the emergence of the history of concepts out of social history. In their almost exhaustive compendium of

Begriffsgeschichte, Ernst Müller and Falko Schmieder note Freyer as background for Conze's engagement with the "epochal threshold of 1800" and Koselleck's commentary of "the industrial society" as well as mention Freyer's theory of historically "satiated" concepts, albeit only as context for Carl Schmitt's parallel endeavors and without giving Freyer much role in the genesis of the approach. ${ }^{12}$ The parallels between Freyer and Begriffsgeschichte, however, are systematic, and I will therefore revisit the link between Freyer and social history -- albeit only insofar as is necessary for adding layers to our comprehension of the genesis of Begriffsgeschichte.

A particularly decisive question is that regarding the relationship between Freyer and Koselleck -- the theorist who gave Begriffsgeschichte its clearest contours. Koselleck's texts contain only few explicit references to Freyer, yet there are numerous point of contention between their respective theories, and indirect evidence suggests Koselleck was familiar with Freyer's work more broadly. ${ }^{13}$ The scholarly remarks on this nexus, however, are very few and sporadic. Perceiving Koselleck as representative of a wider tendency in postwar German historiography, Jin-Sung Chun notes how the young Koselleck shared Freyer's "ambivalent view of the Enlightenment" as well as analyzed, "analogously with Freyer," the Enlightenment in terms of both continuities and discontinuities and traced the progressorientation in eighteenth-century philosophy of history to medieval eschatology. ${ }^{14}$ In his biographical account on Koselleck, Niklas Olsen first summarizes Freyer's influence on Conze and situates Koselleck in Conze's footsteps without, however, commenting on Koselleck's direct engagement with Freyer, and later mentions Freyer as a representative, alongside Löwith, of the general interest in the future orientation and expectations in nineteenth-century thought, thereby relativizing Koselleck's uniqueness in the German mid-

\footnotetext{
${ }^{8}$ Irmline Veit-Brause, "Werner Conze (1910--1986): The Measure of History and the Historian's Measures," in Paths of Continuity: Central European Historiography from the 1930s to the 1950s, ed. Hartmut Lehmann \& James van Horn Melton (Cambridge: Cambridge University Press, 2003), 310.

${ }^{9}$ Thomas Etzemüller, Sozialgeschichte als politische Geschichte: Werner Conze und die Neuorientierung der westdeutschen Geschichtswissenschaft nach 1945 (Munich: Oldenbourg, 2001), 60; Jan Eike Dunkhase, Werner Conze: Ein deutscher Historiker im 20. Jahrhundert (Göttingen: Vandenhoeck \& Ruprecht, 2011), 129-130.

${ }^{10}$ Jin-Sung Chun, Das Bild der Moderne in der Nachkriegszeit: Die Westdeutsche "Strukturgeschichte" im Spannungsfeld von Modernitätskritik und wissenschaftlicher Innovation 1948-1962 (Munich: Oldenbourg, 2000), 34.

${ }^{11}$ Muller, Other God, 357.

${ }^{12}$ Ernst Müller \& Falko Schmieder, Begriffsgeschichte und historische Semantik: Ein kritisches Kompendium (Frankfurt am Main: Suhrkamp, 2016), 214, 276, 306.

${ }^{13}$ The Reinhart Koselleck Library in Deutsches Literaturarchiv (DLA), Marbach, includes Koselleck's exemplars of Freyer's books. Particularly Theorie des Gegenwärtigen Zeitalters and Politische Grundbegriffe have been marked, while Der Staat and Revolution von Rechts are annotated selectively and decorated with marginalia, including question marks to signal reservations on Freyer's ideologically dubious claims. Neither Weltgeschichte Europas nor Schwelle der Zeiten are available in DLA or the Koselleck Library in Timisoara, Romania.

${ }^{14}$ Jin-Sung, Bild, 82-83.
} 
twentieth-century academia. ${ }^{15}$ While these remarks underscore the relevance of the Freyer/Koselleck link, they hardly go beneath the surface. After setting the stage with Brunner and Conze, I will therefore address this relationship directly with regard to several particular topics molding conceptual history.

My reading supplements earlier accounts that have linked conceptual history with radical conservatism. Scholars have particularly assessed Carl Schmitt's role in Koselleck's intellectual formation and the consequences of his mentoring for the methodology of Begriffsgeschichte ${ }^{16}$, but a balanced picture necessitates reckoning with another former radical conservative. Freyer's case, however, is different, given his own postwar attempt at a deradicalization of his political categories, whereas Schmitt never lost his acrimony. Further, while Conze and Brunner engaged directly with Freyer's ideas during the Third Reich, Koselleck, mostly utilizing Freyer's postwar work, seems to have received the politically dubious impulses mediated through his senior colleagues. In linking conceptual history with radical conservatism, my aim, obviously, is not to discredit the approach as politically dubious or inevitably conservative. Rather the proposed links are contingent facts in intellectual history, and their ramifications should be acknowledged and, where appropriate, remedied with more balanced views. The approach of Begriffsgeschichte -- contingently -arose amidst devastating historical-political challenges and out of highly particular substantial interpretations of European history, and to comprehend that particularity is not to deny the merits, or lessen the utility, of the approach. Koselleck once diagnosed Brunner's postwar turn from ideological Volksgeschichte to academic Strukturgeschichte as an example of how "politically conditioned knowledge-interests may lead to theoretically and methodologically novel insights that outlast their initial situation." 17 This formulation is extendable to Koselleck's own work, which developed from political pessimism to mature theorizing of historical times.

I will assess Freyer's role in this transition by means of three thematic interventions. I first analyze Freyer's influence on Brunner's and Conze's history of structures, the key concepts of which Koselleck adopted to his socially oriented conceptual history and his theory of historical times. The next section engages with the parallels in how Freyer and Koselleck, respectively, conceived of history, ideological planning, and concepts in modernity. The last section scrutinizes Freyer's idea of epochal thresholds and its links with Koselleck's saddle time thesis, later reformulated as "threshold time."

\section{Historical Structures and Multilayered Concepts}

In the 1920s and 1930s, Freyer retained the outline of his inherited Hegelianism, yet sought to historicize the study of society and purify it of any traits of telos-oriented philosophy of history. Radically aware of the contemporary relevance of past events and the capacity of particularly political peoples to shape the future, Freyer argued that history consisted of political decisions that accumulated into the whole of world history. This was so, because

\footnotetext{
${ }^{15}$ Niklas Olsen, History in the Plural: An Introduction to the Work of Reinhart Koselleck (New York: Berghahn, 2012), 119-123, 127-128.

${ }^{16}$ Kari Palonen, Die Entzauberung der Begriffe: Das Umschreiben der politischen Begriffe bei Quentin Skinner und Reinhart Koselleck (Münster: Lit, 2004), 51-59; Reinhard Mehring, "Begriffssoziologie, Begriffsgeschichte, Begriffspolitik: Zur Form der Ideenge- schichtsschreibung nach Carl Schmitt und Reinhart Koselleck," In Politische Ideengeschichte im 20. Jahrhundert: Konzepte und Kritik, ed. Harald Bluhm and Jürgen Gebhardt (Baden-Baden: Nomos, 2006); Timo Pankakoski, "Conflict, Context, Concreteness: Koselleck and Schmitt on Concepts," Political Theory 38, no. 6 (2010), 749-779; Olsen, History.

${ }^{17}$ Reinhart Koselleck, "Sozialgeschichte und Begriffsgeschichte," [1986], in Begriffsgeschichten: Studien zur Semantik und Pragmatik der politischen und sozialen Sprache (Frankfurt am Main: Suhrkamp, 2006) [hereafter Begriffsgeschichten], 12n4.
} 
decisions gave rise to historical structures, which then lived longer than the original political impulses. The transition into the industrial society was such a historical shift - and an ongoing process. To bring home these points, Freyer particularly mobilized geological and volcanic metaphors, which I will next analyze in order to later establish links to Brunner, Conze, and Koselleck.

In his political-literary essays, Freyer celebrated political vitality, unpredictability, and ruthlessness. Some things, he noted in 1923, grew through "thousand-year-long stratification [Schichtung]," others through "volcanic moments." 18 Although "the tellurian process of civilization" had gradually built a "crust of civilization" around the Earth "like a geological formation," there were still political powers capable of "bursting through the cover" and "breaking through" the "structure [Gefüge] of historical time" into the unknown future. ${ }^{19}$ Epoch-making political decisions were thus, metaphorically, like outbursts of lava that first smoldered underground and then reshaped the crust of the Earth. In his national-socialist period, Freyer defined politics precisely as the ability to restructure the accumulated historical strata: politics was "volcanic eruption" and "bursting through all that which is widely layered [breitgelagert]," something that only begins where god-like powers "burst from history's molten core of the Earth through the cover of civilization," when "volcanic masses burst through the widely layered and crosswise stratified structure [breitgelagerte und quergeschichtete Gefüge] of grown rocks," and when "political will" breaks through "the peaceful sediment." 20 The irony, however, was that such creative powers would themselves eventually become strata in the accumulating mass they now pierced.

With the very same imagery, Freyer also expressed the contemporary relevance of the past in his sociological writings in the early 1930s. Against Hegel, Freyer posited that history consisted of the accumulation of historical situations into layers (Schichten), not transitions between stages (Stufen) ${ }^{21}$ History was not linear movement toward a pre-set goal, let alone the humankind's advancement on a moral ladder, but the lower strata could resurface at any point. Further, the stratified past was not only something anterior, but also contemporary, because historical reality provided the basis for contemporary events, or the "historical substructure of our own reality." 22 Central social forms like "community" or "class society" were always present as "enclosed [eingelagerte] layers of the overall structure" which "overlay [überlagern] and permeated [durchdringen] each other" so that there were no " "pure' structures," but a "plurality of structural elements" -- and societal reality was therefore "multilayered" (vielschichtig). ${ }^{23}$

This general idea and the supporting imagery remained in Freyer's moderately conservative postwar work: for him, history was "the stratification [Schichtung] of the world in which we currently live ... just like the Earth is the stratified structure of layers and eruptions [Schichtengefüge der Lagen und Eruptionen]." ${ }^{24}$ Yet it was crucial to pay in mind, Freyer noted, that such "deep stratification [Tiefenschichtung]"25 emerged through political decisions, and historical layers testified to the successes or failures of past political projects. History, Freyer posited, happened "through" such "crosswise striped [quergestreift]" material $^{26}$-- just like he earlier defined politics as the ability to pierce "crosswise stratified"

\footnotetext{
${ }^{18}$ Freyer, Prometheus, 9.

${ }^{19}$ Ibid., 53-55, 58, 111-112.

${ }^{20}$ Hans Freyer, Pallas Athene: Ethik des politischen Volkes (Jena: Diederichs, 1935), 39-40.

${ }^{21}$ Freyer, Soziologie, 217.

${ }^{22}$ Ibid., 89.

${ }^{23}$ Freyer, Einleitung, 128-129.

${ }^{24}$ Freyer, Theorie, 177 . Koselleck has heavily underlined this passage in his exemplar.

${ }^{25}$ Freyer, Weltgeschichte, I, 148.

${ }^{26}$ Hans Freyer, "Soziologie und Geschichtswissenschaft," [1952], reprinted in Geschichte und Soziologie, ed. Hans-Ulrich Wehler (Köln: Kiepenheuer \& Witsch, 1972), 79-80.
} 
rocks, and occasionally the course of history was changed in "a sudden re-stratification of the temporal structure [Umlagerung der Zeitstruktur]." ${ }^{27}$ The model of history as geology was thus inherently linked with the political aspect: history was political through and through, and the current world was a stratified product of past political decisions. This compound of history and politics remained intact when Freyer "deradicalized" his theory into a melancholy, rather than militant, version of conservatism.

Crucially, the observation of such decision-based structures also facilitated the historical relativization of current structures: particularly Freyer's main target, the civil society, was not a natural form of social life, but a product of "a certain division of wealth, a certain valid legal order, a certain stratification [Lagerung] of political forces, and a certain intellectual situation." ${ }^{28}$ German sociology, Freyer claimed, should promote the concepts of state and people (Volk) against the foreign idea of 'society': in fact, society should be overcome with "higher forms of community," relying on "deeper forces and structures." ${ }^{29}$ For Freyer, the historical relativization of "society' was merely the first step toward transcending this alien category altogether in favor of the unified Volk, and sociology was to play a key role in this political mission, as Freyer proclaimed at the height of his radical period. The same point of society not being "a historically neutral category," but a result of an "overall situation [Gesamtlage] through which the stream of historical events runs," however, was clearly spelled already in his 1930 program for historical sociology. ${ }^{30}$

The above theorizing guided German structural history in its formative period and, I claim, also shaped the emergence of conceptual history. Werner Conze is usually credited for coining the term "the history of structures" (Strukturgeschichte). Yet, as Dunkhase points out, this was mostly a terminological change, because Brunner had spoken of structures all along without, however, using the exact expression "Strukturgeschichte." 31 Conze coined the term first in French as 'histoire des structures' in a review of Braudel's La Méditerraneé in 1951 and a year later in the eventual German form, again evoking Braudel's authority. ${ }^{32}$ However, as Dunkhase notes, Braudel never used the exact term 'the history of structures' in $L a$ Méditerraneé and invoked 'structures' sparingly, whereby it appears problematic to trace Conze's key term to Braudel. ${ }^{33}$ Rather what Conze inherits ostensibly from Braudel, I propose, is the Freyerian emphasis on accumulated historical strata. The vocabulary of structures and the associated geological imagery are significantly more dominant in Freyer than Braudel, and Conze's programmatic essays in the 1950s are full packed with explicit and implicit references to Freyer. Conze coined the term Strukturgeschichte out of material gradually accumulated in the work of Freyer, Brunner, and Braudel in a manifold process of filtration, based on direct personal engagement. ${ }^{34}$ Instead of being "based on a misunderstanding of the concept of structure developed in the discussion between French

\footnotetext{
${ }^{27}$ Hans Freyer, Machiavelli (Leipzig: Bibliographisches Institut, 1938), 123.

${ }^{28}$ Hans Freyer, "Gegenwartsaufgaben der deutschen Soziologie," Zeitschrift für die gesamte Staatswissenschaft 95, 1935, 116-144, 120-121.

${ }^{29}$ Ibid, 127.

${ }^{30}$ Freyer, Soziologie, 67.

${ }^{31}$ Dunkhase, Werner Conze, 133-134.

${ }^{32}$ Ibid. 138 .

${ }^{33}$ Ibid.

${ }^{34}$ Freyer's influence on Brunner and Conze came partly mediated through one of their mentors, the historian Hans Rothfels (Jin-Sung, Bild, 53-54). However, they also socialized with Freyer directly. In 1930-31, Conze studied in Leipzig where Freyer served as a professor of sociology, and from 1951 to 1957 Conze was in Münster, where Freyer taught as an emeritus from 1953 to 1963 and wrote his Theorie des gegenwärtigen Zeitalters -- in both occasions, Freyer had "substantial influence on Conze's historical thought," as noted by Dunkhause (Werner Conze, 23 and 75). Also Brunner interacted with Freyer, for instance co-organizing a workshop in 1952 (Muller, "'Historical Social Science,"” 228).
} 
historians and structuralists," as Hans-Ulrich Wehler once polemicized ${ }^{35}$, Strukturgeschichte thus rather relied on domestic impulses, only seasoned with further French reflections on time.

Three Freyerian points are pertinent here. First, social structures were inherently political in that they emerged and dissolved on the basis of political events and decisions. Like Freyer, Brunner and Conze denied the demarcation between social and political history. When reading Brunner's 1954 remark on the alleged difference between social history and political history, Conze forcefully denied any such distinction -- a point adopted by Brunner in a 1956 revision. ${ }^{36}$ Conze's remark appears slightly patronizing, as Brunner had already in 1936 observed the need of human communities for inner order and the capability to defend themselves, whereby they were of "historical-political nature," and "all history" was "political history," as noted directly after an explicit reference to Freyer's idea of sociology as a science of reality. ${ }^{37}$ After the war, Conze marketed this idea and retained the link to Freyer: there were no social formations that would not have emerged politically, and Braudel's levels of the history of structures and the history of events mutually conditioned each other, Conze noted ${ }^{38}$ -- in other words: structures not only guided events, but contingent political events also produced structures. Both history and sociology, Conze observed, studied the society, which was "always structured in the particular political order" and was "a structured order of authority" -- a phrase Conze put in inverted commas and attributed to Freyer. ${ }^{39}$ The study of history was thereby "political" even when it had social phenomena as its objects. ${ }^{40}$ This perspective followed effortlessly from the political-theoretical assumptions behind Freyer's "structures" and the way Freyer himself utilized these categories in historical analysis in Weltgeschichte Europas. In an essay that made references to that volume and two other texts by Freyer, Brunner noted that just as little as the actions of social formations could be understood without studying their inner construction could "the relatively enduring structures" be comprehended "independently of political events." 41 The Freyerian perspective of political decisions affecting history was particularly salient in Conze, who in 1949 lauded Weltgeschichte Europas for its "truly exciting presentation of decisions related to world history" and in 1957 argued for the inseparability of political and social history by emphasizing the need to take "political struggle and political decisions" into account. ${ }^{42}$

Second, the structures lasted longer than the political impulses that brought them about: they thus provided historical continuity and carried contemporary relevance. Conze spelled this point in unmistakably Freyerian quasi-geological language. Alluding to Freyer's notion in inverted commas, he described the task of structural history as that of studying "the contemporary era" by means of "empirical-historical research on its historical stages, strata, and structural connections." ${ }^{43}$ In a 1952 essay, he explicitly cited Freyer's note from the same

\footnotetext{
${ }^{35}$ Cited in Muller, “"Historical Social Science,"” 197.

${ }^{36}$ Dunkhase, Werner Conze, 135.

${ }^{37}$ Otto Brunner, "Zum Problem der Sozial- und Wirtschaftsgeschichte," Zeitschrift für Nationalökonomie 7, no. 5 (1936), 671-685, 677

${ }^{38}$ Werner Conze, "Sozialgeschichte," [1966], in Gesellschaft -- Staat -- Nation: Gesammelte Aufsätze, ed. Ulrich Engelhardt, Reinhart Koselleck \& Wolfgang Schieder (Stuttgart: Klett-Cotta, 1992) [hereafter GSN], 91.

${ }^{39}$ Werner Conze, "Die Stellung der Sozialgeschichte in Forschung und Unterricht," Geschichte in Wissenschaft und Unterricht 3 (1952), 655-656.

${ }^{40}$ Ibid., 654.

${ }^{41}$ Otto Brunner, "Das Problem einer europäischen Sozialgeschichte," [1954], in Neue Wege der

Sozialgeschichte: Vorträge und Aufsätze (Göttingen: Vandenhoeck \& Ruprecht, 1956) [hereafter NW], 9.

${ }^{42}$ Werner Conze, [Review of Hans Freyer, Weltgeschichte Europas, 1948], Deutsche Universitätszeitung 4, no. 23 (1949), 16; Werner Conze, "Die Strukturgeschichte des technisch-industriellen Zeitalters als Aufgabe für Forschung und Unterricht," [1957], in GSN, 77.

${ }^{43}$ Werner Conze, "Die Gründung des Arbeitskreises für moderne Sozialgeschichte," Hamburger Jahrbuch für Wirtschafts- und Gesellschaftspolitik 24 (1979), 28.
} 
year that history must be reflected in a "crosswise striped [quergestreift]" manner. ${ }^{44}$ On the very same page, Conze discussed Braudel and coined the term "Strukturgeschichte" - but the metaphors evidently came from Freyer.

Third, concepts were embedded in politically constituted and historically accumulated structures. This aspect serves to show how subtly the historicity of concepts in Begriffsgeschichte emanated from the historicity of social structures. In 1952, Freyer noted the risk inherent in formalizing concepts stemming from "the industrial society," such as 'classes,' 'class struggle,' or 'ideology,' and transferring them onto feudal social settings. ${ }^{45}$ In an essay published in the selfsame journal later that year, Conze correspondingly noted the late emergence of 'economy', 'society,' and 'state' in modernity and asked whether 'proletariat,' 'capitalism,' and 'class' were concepts specific to "the modern industrial society." ${ }^{" 46}$ Rather than being an ephemeral postwar similarity, this link derived from prewar interaction between Freyer and Brunner. In Soziologie als Wirklichkeitswissenschaft (1930), Freyer analyzed sociology as a historical formation reflecting the societal reality of a particular era. Consequently, sociological concepts like 'class,' 'proletariat,' 'metropolis,' or 'state' reflected the reality and problems of a particular social order, were "historically saturated" 47 and characterized by "historical boundedness," and, in order to be properly comprehended, had to be tied to the "historical situation" and the "epoch." "48 Sociological categories like 'oikos,' 'metropolis,' 'slavery,' 'caesarismus,' 'estate,' 'state,' or 'society' were thus qualitatively different from the general concepts of natural science. ${ }^{49}$ Rather than being "timelessly valid concepts," for instance 'patriarchal princehood,' 'free competition,' or 'free labor market' were valid only for a while.$^{50}$ Freyer's attempt to historicize sociology entailed the endeavor of freeing historical reflection of Hegelian teleology, and one crucial aspect of this was the reinterpretation of concepts as historically satiated categories with social and political relevance rather than as supra-historical philosophical abstractions that merely unfolded in world history. This, however, did not entail unrestrained relativism, but the stratified model rather served to secure historical continuities. "Logos" was to be replaced with "reality," on the one hand, but "steps" (Stufen) in the world-historical process also supplemented with "layers" (Schichten) ${ }^{51}$ that remain in effect longer, thus unifying past and future, on the other.

Freyer's perspective profoundly inspired Brunner. Freyer for instance proposed that the significance of medieval poetry could not be comprehended without the concepts of chivalry and feudalism and "the whole societal structure of the medieval world." 52 This was the perspective Brunner would generalize in Land and Lordship (1939), arguing that historians had anachronistically projected the modern state/society distinction onto their medieval sources. Brunner, famously, built on Schmitt's ideas of political communities as "concrete orders" 53 in an attempt to find new spatial and social groundings for political communities, thereby providing an alternative to the shallow liberal doctrines. Yet, the perspective also -and for the emerging conceptual history, more decisively -- built on Freyer's point on the historical saturation of concepts. In a 1936 review, Brunner noted that the historian was

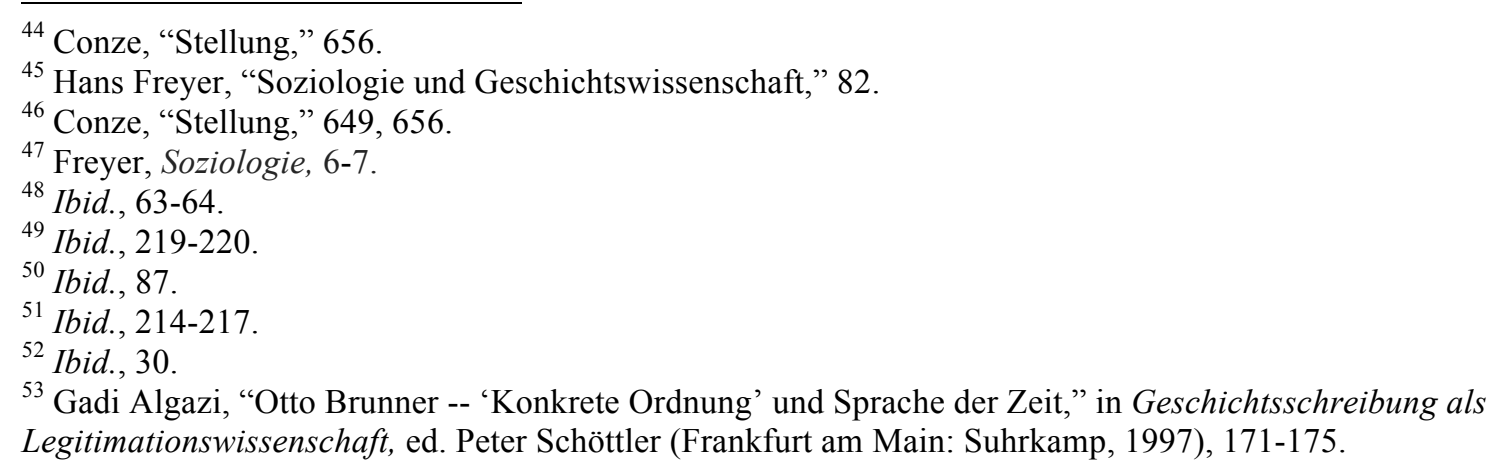


engaged not with the historical genesis of individual phenomena, but with "the historical becoming of his own world, the concrete formations of folk and state, in which he lives," thus stating the contemporary relevance of studying past political structures which he would express more forcefully in Land und Herrschaft. Brunner also noted, with explicit reference to Freyer, that sociology was a "science of reality," yet itself bound up with the bourgeois society, and that its concepts were therefore not directly transferable to preceding epochs. ${ }^{55}$ Key categories were not to be "liberated from the current overall structure [Gesamtgefüge]" and "the concrete economic structures." ${ }^{56}$ In the book under review, the historian Ernst K. Winter, however, had done precisely that: invoking concepts like "the state," "economy," "social policy," "feudalism," "capitalism," and "socialism," which in Brunner's formulation "belonged to the nineteenth century," Winter manifested the "deficiency of transferring the sociological conceptual world of today to the middle ages." "When these points recurred in Land und Herrschaft, Brunner had retained, and in fact augmented, the references to Freyer as the authoritative antipode of such anachronism; after the war, however, he omitted the references completely, thus obscuring the link between himself and Freyer for those using the nowadays widely available 1965 edition. ${ }^{58}$

Further, Freyer fundamentally shaped Brunner's observations of what hindered contemporary scholars from seeing the medieval world in its own conceptual terms -the modern industrial society. In the early 1930s, Freyer noted that European sociology was, through its own genesis, tied to specific eighteenth- and nineteenth-century forms of thought, such as the optimistic and progress-oriented philosophy of history and the state/society division. ${ }^{59}$ Freyer posited that the Germans still thought like the nineteenth century, but envisioned the key ideas of that epoch were now dissolving, actively calling for a revolution from the right to overcome the liberal epoch and what remained of the nineteenth-century "industrial society." ${ }^{60} \mathrm{He}$ anticipated the semi-mythological Volk ${ }^{61}$ to emerge as a counterforce and to "break from below into the plain of the industrial society, crosswise through all its conflicts of interests." 22 The volcanic model suggested the ability of the political Volk to reorganize social structures, yet, through the idea of lava again solidifying, the image also implied the continuing presence of the Volk. The double metaphor is far from insignificant. As Muller importantly emphasizes, for Freyer, "the Volk remained an ongoing historical reality ... upon which later social structures were based." $"$ F3 Freyer indeed underscored Volk as the most relevant form of community for "the European present" and described this with the habitual vocabulary of "overlying," "underground," "structures," and "layers." ${ }^{64}$ While 'society' was merely a product of a specific liberal epoch, for Freyer 'Volk' could, perplexingly, escape such narrow confines: the proper object of sociology was the trans-historical Volk in its various "historical ways of life." 65

\footnotetext{
${ }^{54}$ Brunner, "Problem der Sozial- und Wirtschaftsgeschichte," 677.

${ }^{55}$ Ibid., 680.

${ }^{56}$ Ibid., 674, 676 .

${ }^{57}$ Ibid., 682, 685 .

${ }^{58}$ Otto Brunner, Land und Herrschaft: Grundfragen der territorialen Verfassgunsgeschichte Südostdeutschlands im Mittelalter, second edition (Brünn: Rohrer, 1942), 132; Otto Brunner, Land und Herrschaft: Grundfragen der territorialen Verfassungsgeschichte Österreichs im Mittelalter, fifth edition (Darmstadt: Wissenschaftliche Buchgesellschaft, 1984[1965]), 119.

${ }^{59}$ Freyer, Soziologie, 7-10.

${ }^{60}$ Freyer, Revolution, 7, 19-35.

${ }^{61}$ Freyer, Revolution, 37-55; Hans Freyer, Das Politische Semester: Ein Vorschlag zur Universitätsreform (Jena: Diederichs, 1933), 35-40.

${ }^{62}$ Freyer, Revolution, 44, 49, 54.

${ }^{63}$ Muller, "“Historical Social Science,"” 209.

${ }^{64}$ Freyer, Soziologie, 229, 252.

${ }^{65}$ Hans Freyer, Gesellschaft und Geschichte (Leibniz: Teubner, 1937), 17.
} 
Brunner similarly saw the state, culture, and the social structure as condensed in the concepts Volk and Reich, whereby history from the Middle Ages to the present could be written as a single Volksgeschichte -- provided one glossed over nineteenth-century liberalism. Brunner's ideas coalesced not only with Schmitt's theorizing of concrete orders, but also with Freyer's ideological opposition between the Volk and the industrial society. Brunner's call for tracing "basic concepts" (Grundbegriffe) to the original and concrete social forms was directly related to the attempt to think around the liberal nineteenth-century framework that jeopardized true historicity. ${ }^{66}$ In fact, echoing Freyer's considerations, Brunner explicitly noted that the "conceptual apparatus of the nineteenth century" had to be "destroyed." ${ }^{\prime \prime 7}$ In underlining what we would now call the "contextual" approach, Brunner, nevertheless, implied the transhistorical relevance of some key concepts. The particular political version of historicism, which Brunner inherited from Freyer, did not relativize the past into a completely foreign country, but, on the contrary, rather underlined its relevance for the present via the category of the Volk.

After the war, Brunner changed his terminology and simply substituted Strukturgeschichte for Volksgeschichte. ${ }^{68}$ In 1948, he rather spoke of "social history," still, however, insisting that medieval social structures could not be understood with the concepts of 'society,' 'class,' and 'estate' alone, but categories like 'authority' and 'cooperative association' had to be included in the analysis ${ }^{69}$ and the "whole inner structure [innere Struktur] of the land in question" considered. ${ }^{70}$ Expanding this perspective, Brunner later advised historians to analyze the entire "inner structure [inneres Gefüge] of the West." ${ }^{\text {"71 }}$ By introducing the language of 'structures,' Brunner effectively toned down the political ramifications of his methodology, yet did not thereby become any less Freyerian. Both Volk and Struktur/Gefüge were crucial parts of Freyer's vocabulary, and Brunner's shift, I posit, was a change of emphasis within the Freyerian theoretical space rather than a breakaway from it.

Importantly, Gefüge was the term Freyer used in linking concepts with social structures: "Only in being historically satiated are sociological concepts capable of carving out the structure [Gefüge] of a given social order in full clarity." ${ }^{, 72}$ Brunner read 'feudalism', 'authority,' and 'cooperative association' as such historically satiated basic concepts, refilled in historical circumstances and thereby capable of informing us about the social reality of the era. Koselleck later similarly spoke of conceptual "structures," yet altered the perspective: rather than scrutinizing the relationship between social structure and individual concepts directly, like Freyer and Brunner, he related each historical concept to the overall conceptual structure (Begriffsgefüge) and analyzed concepts' interrelations and each concept's weight

\footnotetext{
${ }^{66}$ James Van Horn Melton, "From Folk History to Structural History: Otto Brunner (1898-1982) and the Radical-Conservative Roots of German Social History," in Paths of Continuity: Central European Historiography from the 1930s to the 1950s, ed. Hartmut Lehmann \& James van Horn Melton (Cambridge: Cambridge University Press, 2003), 278.

${ }^{67}$ Brunner, Land und Herrschaft (1942), 495.

${ }^{68}$ Van Horn Melton, "Folk History," 291-292. Conze switched from folk history to structural history in an equally straightforward way, as noted in Reinhart Koselleck, "Werner Conze: Tradition und Innovation," Historische Zeitschrift 245, no. 1 (1987), 536.

${ }^{69}$ Otto Brunner, "Sozialgeschichtliche Forschungsaufgaben, erörtet am Beispiel Niederösterreichs," Anzeiger der österreichischen Akademie der Wissenschaften: Philosophisch-Historische Klasse 23 (1948), 337.

${ }^{70}$ Ibid., 341.

${ }^{71}$ Otto Brunner, "Inneres Gefüge des Abendlandes," in Historia Mundi: Ein Handbuch der Weltgeschichte in zehn Bänden, Sechster Band: Hohes und Spätes Mittelalter, ed. Fritz Valjavec (Bern: Francke, 1958), 318-385.

${ }^{72}$ Freyer, Soziologie, 218.
} 
within the structure ${ }^{73}$, linking the overall conceptual structure to the current social structure (soziale Gefüge) only on the next level of analysis. ${ }^{74}$

However, concepts' embeddedness in social structures not only enabled them to communicate something about the whole historical epoch, but also ensured that their relevance was not confined to the particular epoch. For Freyer, history was the "stratification of the world in which we currently live" just like the Earth was a "stratified structure of the layers and eruptions" of which it had accumulated; but while in geology materials could only lay on top of each other, or side by side, in intellectual life much remained "lively and active" -- that is, past formations carried contemporary relevance. ${ }^{75}$ In my interpretation, this perspective fed into Koselleck's basic categories, particularly in the early 1970s when he reengaged with the relationship between social history and Begriffsgeschichte. It was crucial, Koselleck proposed, to supplement the synchronic with a diachronic perspective, which could "uncover layers [Schichten] that remained concealed in the spontaneous use of language."76 Conceptual history indeed sought to clarify such "multilayeredness [Mehrschichtigkeit] of meanings chronologically stemming from various times" within a single concept ${ }^{77}$ and to map the "the historical depth [Tiefenlage] of a concept." ${ }^{, 78}$ Further, rather than being dead stone, these gradually or abruptly formed layers structured the ways in which we experienced the world, and past things were therefore always things of the present. Precisely the task of mapping the various strata precluded any strict diachrony/synchrony dualism and called for recognition of "the contemporaneity of the non-contemporaneous that may be incorporated in a concept.",79 Language thus contained "differently staggered temporal deep structures [verschieden gestaffelte zeitliche Tiefenstrukturen]," "chronologically differently classifiable layers [zeitlich verschieden einzustufende Schichten]." 81

The geological metaphor is an essential part of the idea of the presence of the past, which Koselleck repeatedly expressed with the phrase "the contemporaneity of the noncontemporaneous" (Gleichzeitigkeit des Ungleichzeitigen). This formulation, stemming originally from Ernst Bloch, is a popular topos in German historical and cultural commentary, and both Freyer and Koselleck are important links in its development, as Achim Landwehr notes without, however, explicating the relationship between them. ${ }^{82}$ In 1955 , Freyer formulated the idea as follows:

"One does not even have to look at the whole Earth to get the impression of the contemporaneity of the non-contemporaneous [Gleichzeitigkeit des Nicht-

Gleichzeitigen]. Also in a single location there can be several epochs side by side, on top of each other, or one below the other." 83

Already Freyer thus expresses the idea of the coexistence of various temporal elements as well as the spatial and geological depiction of these elements as horizontal layers in vertical

\footnotetext{
${ }^{73}$ Reinhart Koselleck, "Richtlinien für das Lexikon politisch-sozialer Begriffe der Neuzeit," Archiv für Begriffsgeschichte 11 (1967), 89.

${ }^{74}$ Koselleck, "Begriffsgeschichte und Sozialgeschichte," [1972], in VZ, 124.

${ }^{75}$ Freyer, Theorie, 177.

${ }^{76}$ Koselleck, "Begriffsgeschichte und Sozialgeschichte," 125.

${ }^{77}$ Ibid., 125.

${ }^{78}$ Ibid., $125-126$

${ }^{79}$ Ibid., 125.

${ }^{80}$ Reinhart Koselleck, "Sprachwandel und Ereignisgeschichte," [1989], in Begriffsgeschichten, 44.

${ }^{81}$ Reinhart Koselleck, sections I and III-VI in "Fortschritt," in Geschichtliche Grundbegriffe: Historisches Lexikon zur politisch-sozialen Sprache in Deutschland, ed. Otto Brunner, Werner Conze \& Reinhart Koselleck [hereafter $G G$ ], Band 2: E-G (Stuttgart: Klett, 1975), 399.

${ }^{82}$ See Achim Landwehr, "Von der "Gleichzeitigkeit des Ungleichzeitigen," Historische Zeitschrift 295, no. 1 (2012), 1-34.

${ }^{83}$ Freyer, Theorie, 7-8.
} 
settings, and in his exemplar, available in the German Literature Archive, Koselleck has underlined the term Gleichzeitigkeit des Nicht-Gleichzeitigen. Koselleck later recapitulates these ideas forcefully and identically invokes the contemporaneousness topos:

"The term 'temporal layers' refers, like its geological predecessor, to multiple layers of time with different durations and different origins that, however, are simultaneously present and effective. 'Temporal layers' also capture the contemporaneousness of the non-contemporaneous." 84

Although Koselleck only explicitly addressed the geological metaphors in his late work, these had accumulated for years. In Preußen zwischen Reform und Revolution (1967), Koselleck applied the layered model of social history to early-nineteenth-century judicial, political, and social structures in Prussia, mapping their "overhangs, seams and breakages" (Überhänge, Naht- und Bruchstellen) and considering "the various layers of historical time." ${ }^{, 5}$ In another context, Koselleck credited Braudel for the crucial suggestion to study historical time in its various layers and noted that if we only focus on linear progress, we miss the "wide plinth [Sockel] of all the structures that endure." geological underpinnings is easy to associate with Braudel -- particularly as Koselleck himself proposes this link. However, while Braudel still suggested that the three temporal levels were parts of a single "homogeneous time of the historian" as opposed to the discontinuities proposed by sociologists, Koselleck renounced this assumption in favor of multilayered non-synchronicity. ${ }^{87}$ I propose Freyer's notes on continued presence of the past through the model of geological strata and the synchronicity of the non-synchronous were instrumental in this transition. The Koselleckian multilayeredness of historical concepts arose out of the Freyerian multilayeredness of social reality via the history of structures à la Conze and Brunner.

As Koselleck notes in a 1999 interview, he got acquainted with Braudel in Heidelberg through Conze, who also regularly spoke about Braudel's three-layered time to him, but Koselleck does not recall having utilized Braudel's 1958 essay on the longue durée directly, adding only that he "must have read it at some point." appears rather flimsy; rather than the exclusive source for Koselleck's imagery of temporal layers, Braudel, who also knew Freyer's and Brunner's work ${ }^{89}$ and socialized with Conze, can be seen as one contributor in a wider postwar debate. Despite his influential longue durée notion and its occasional accompanying geological imagery, Koselleck's metaphorical language seems primarily to derive from the Freyer reception amongst proponents of Strukturgeschichte. To trace a metaphor exclusively to a single author would be to misconceive the very nature of metaphors as linguistic resources equally at everybody's disposal once they have been uttered, and particularly in the German postwar cultural debates thinkers freely adopted each other's categories. However, given Freyer's undeniable impulses to Koselleck's closest collaborators Brunner and Conze and Koselleck's own demonstrated reading of Freyer, the linguistic parallels between Freyer and Koselleck appear as far from coincidental. Helge Jordheim's note that Koselleck derived the notion of structure not from

\footnotetext{
${ }^{84}$ Koselleck, "Einleitung," in Zeitschichten: Studien zur Historik (Frankfurt am Main: Suhrkamp, 2000) [hereafter Zeitschichten], 9.

${ }^{85}$ Reinhart Koselleck, Preußen zwischen Reform und Revolution: Allgemeines Landrecht, Verwaltung und soziale Bewegung von 1791 bis 1848 (Stuttgart: Klett, 1967), 14.

${ }^{86}$ Koselleck, "Moderne Sozialgeschichte und historische Zeiten," [1982/1980], in Zeitschichten, 327.

${ }^{87}$ Helge Jordheim, "Introduction: Multiple Times and the Work of Synchronization," History and Theory 53, no. 4 (2014), 503-508.

${ }^{88}$ Koselleck in "Zeit, Zeitlichkeit und Geschichte - Sperrige Reflexionen: Reinhart Koselleck im Gespräch mit Wolf-Dieter Narr und Kari Palonen (1999)," in Zeit, Geschichte und Politik: Zum Achtzigsten Geburtstag von Reinhart Koselleck (Jyväskylä: University of Jyväskylä, 2003), 11.

${ }^{89}$ Fernand Braudel, Écrits sur l'histoire (Paris: Flammarion, 1969), 177, 188, 288.
} 
structural linguistics but from the pre-WWII Strukturgeschichte is correct, ${ }^{90}$ but deserves to be supplemented by noting that as far its functions and imagery were concerned, Koselleck's notion of structures reworked Conze's Freyerian starting points.

This is not to say that Koselleck's would not have gone significantly beyond Freyer's perspectives; Koselleck's suggestion that the various temporal layers can also be detected within individual concepts ${ }^{91}$, and concepts thus utilized as means of studying prevailing or repetitive structures, opens new vistas to the study of history in general and European modernity in particular. However, this methodological step, I argue, was contingently and decisively prepared by Freyer's twofold contribution: first, his note on the epochboundedness and historically satiated nature of concepts and their concomitant ability to provide information on past social structures, and second, his observation on the simultaneous presence of multiple past epochs in each contemporary moment, expressed in geological terms. As soon as we refuse to consider these suggestions separately and rather apply the latter theorem to the former, it follows that the key concepts of a certain era reflect its layered experiences and are invariably loaded with material deriving from previous epochs, and that this is by no means the case only for the "contemporary era" Freyer perceived as politically and intellectually problematic. On the basis of the layered model, concepts gain their ability to express not only the past, but also the past of the past, not to mention the often politically conditioned past futures. Koselleck combined the two perspectives into a formal theory of historical times, partly based on Freyerian elements mediated through Brunner and Conze.

\section{History, Planning, and Concepts in Political Modernity}

Koselleck's idea of the internal temporalization of concepts rested upon a set of more general theoretical propositions and historical hypotheses that accumulated since the 1950s -- under the influence of Freyer's cultural philosophy, I argue. For the young Koselleck, the modern world emerged from the Enlightenment philosophers' hypocritical engagement with the ancien régime in ostensibly neutral, but in reality moral and political categories, and the assault was legitimized, and the ensuing crisis covered, with a progress-oriented philosophy of history. ${ }^{92}$ This political maneuver had historical and conceptual implications, which Koselleck theorized more generally in the 1960s and 1970s. During the "saddle time," the former many histories were replaced by a single and supposedly unified history, whereby history also became more easily foreseeable, manageable, and ostensibly capable of being planned on the basis of utopian ideology. Expectations surpassed experiences, and the past, the present, and the future were torn apart. These arguments had direct conceptual implications and underlay the heuristics of Begriffsgeschichte: after a "temporalization" of concepts during the saddle time, modernity was characterized by increased contestation with future-oriented categories and, consequently, by permanent ideological controversy, both traceable to the late-eighteenth-century political crisis. ${ }^{93}$

Koselleck's early work famously contained elements from Schmitt, Löwith, Heidegger, Gadamer, and others, ${ }^{94}$ but I will supplement the picture with observations on Freyer's contributions, using the criticism of the philosophy of history as an inlet into the thematics

\footnotetext{
${ }^{90}$ Helge Jordheim, “Against Periodization: Koselleck's Theory of Multiple Temporalities,” History and Theory 51, no. 2 (2012), 165.

${ }^{91}$ Reinhart Koselleck, “'Neuzeit': Zur Semantik moderner Bewegungsbegriffe,” [1977], in VZ, 344.

${ }^{92}$ Reinhart Koselleck, Kritik und Krise: Eine Studie zur Pathogenese der bürgerlichen Welt (Frankfurt am Main: Suhrkamp, 1959).

${ }^{93}$ Koselleck, "Richtlinien"; Reinhart Koselleck, "Einleitung," in GG, Band 1: A-D (Stuttgart: Klett, 1972), XIIIXXVII; Koselleck, VZ.

${ }^{94}$ Olsen, History.
} 
shared by both Freyer and Koselleck. Earlier research has traced Koselleck's engagement with the philosophy of history primarily to Löwith, which is plausible per se, given that Koselleck and Hanno Kesting, who were also involved in translating Meaning in History $(1949 \text {, German edition 1953 })^{95}$, were obviously inspired by the volume. So was, however, Freyer, who found in Löwith's book many familiar arguments. Freyer had criticized "the philosophy of history" already in the $1920 \mathrm{~s}^{96}$, called for the liberation of sociology from eighteenth-century philosophy of history by Turgot, Saint-Simon, Comte, and others, in the $1930 \mathrm{~s}^{97}$, and analyzed philosophy of history as secularized eschatology in the $1940 \mathrm{~s}^{98}$, before assaulting present-day political "chiliasm," with explicit reference to Löwith, in $1955 .{ }^{99}$ There are five parallels between Freyer's and Koselleck's respective critiques of the philosophy of history I wish to note.

First, both authors underscored the plural and open-ended nature of history in opposition to the singularity, directedness, and inevitability postulated by the Enlightenment philosophy of history. The criticism of the philosophy of history was an essential part of Freyer's struggle with the Hegelian heritage and his attempt to jettison any residues of telos-oriented metaphysics from historical sociology in the 1930s -- and thus predates the Cold War. Freyer saw no goal or direction in history, but only contingency and particularity. This entailed the idea that, in the absence of a Hegelian overarching principle, world-history was essentially plural, rather than unified as claimed by Geschichtsphilosophie. Already in 1923, Freyer noted that "history thinks in plurals" 100 and criticized the "Voltaire-like" belief in steady progress which attempted to mold human history as a "unity" rather than "plurality"101, and after WW2, he forcefully restated the "plurality" of history as opposed to the fictional world unity, underpinned by modern liberal or Marxian philosophies of history. ${ }^{102}$ History was essentially "open." "103 Further, progress-oriented philosophy of history was wrong also in depicting history as irreversible steps, while any empirical progress in history was only relative and always restricted by the continued presence, and possible reactivation, of earlier layers. The criticism of the philosophy of history thus contributed to the same goal as the framework of geological stratification, analyzed earlier.

These criticisms shed new light also on how Koselleck conceived history as open-ended and plural ${ }^{104}$-- an aspect particularly emphasized by Niklas Olsen. ${ }^{105}$ In my view, Olsen correctly underscores the link between Koselleck's emphasis on the plurality of history and the theory of temporal layers. ${ }^{106}$ To me, however, instead of showing the Löwithian nature of Koselleck's criticism of Heidegger's individualist orientation in history, this link rather underlines the extent to which Koselleck operated in a Freyerian framework. This interpretation is supported by the fact that, in his exemplar, Koselleck has underlined three

\footnotetext{
${ }^{95}$ Dirk van Laak, Gespräche in der Sicherheit des Schweigens: Carl Schmitt in der politischen Geistesgeschichte der frühen Bundesrepublik (Berlin: Akademie, 2002), 272.

${ }^{96}$ Hans Freyer, Die Bewertung der Wirtschaft im philosophischen Denken des 19. Jahrhunderts (Hildesheim: Olm, 1966[1921]), 63-69, 73-76.

${ }^{97}$ See Freyer, Soziologie, 116-121.

${ }^{98}$ Freyer, Weltgeschichte, II, 875.

${ }^{99}$ Freyer, Theorie, 207.

${ }^{100}$ Freyer, Prometheus, 78.

${ }^{101}$ Ibid., 49.

${ }^{102}$ Freyer, Weltgeschichte, I, IX-X; II, 793, 965; Freyer, Theorie, 248-249, 252, 256

${ }^{103}$ Freyer, Theorie, 247.

${ }^{104}$ See particularly, Reinhart Koselleck, "Wozu noch Historie?," [1970], in SUG, 32-51.

${ }^{105}$ Olsen, History, 4-5, 147-148, 303-304.

${ }^{106}$ Ibid., 67, 229-230. Niklas Olsen, "Reinhart Koselleck, Karl Löwith und der Geschichtsbegriff," in Zwischen Sprache und Geschichte: Zum Werk Reinhart Kosellecks, ed. Carsten Dutt \& Reinhard Laube (Göttingen: Wallstein, 2013), 248.
} 
passages where Freyer evokes the "pluralism of the historical world." ${ }^{\prime 107}$ For both thinkers, the notion of temporal layers and the contemporaneity of the non-contemporaneous arose out of the rejection of the single linear progress postulated by the Enlightenment thinkers for political purposes -- the emphasis on historical plurality was thus internally linked with the multilayeredness of history, and both were intertwined in the criticism of the philosophy of history. While other scholars expressed ideas similar to those of plurality and multilayeredness, respectively, their combination and Koselleck's actual use of them suggest inspiration from Freyer.

Second, both thinkers resisted the idea that history could be planned. Like the goalorientation of unified history, also this aspect emerged out of Christian eschatology by secularization of the divine plan: while leaving room for human rationality and judgment, the figure of thought, with reference to the inevitability of salvation, also ensured that the human plan would actually unfold. Freyer had been analyzing the relationship between planning and political power since the $1930 \mathrm{~s}^{108}$, and in his postwar work he criticized the ideas of "makeability" (Machbarkeit) and the "perfectability of history" behind Cold War ideological planning. The doctrine of perfectability presumed erroneously that history could be "made" or "planned," which was a utopian aspiration and, further, easily turned violent in executing the plan, as evinced by the Jacobin terror. ${ }^{109}$ This was the perspective that was carried over from Koselleck doctoral dissertation to his mature work. In Kritik und Krise, Koselleck first invoked the Enlightenment "misunderstanding" of history as something "plannable" (planbar), and later analyzed how the philosophy of history legitimized such utopian planning of the future, gave contingent choices an aura of inevitability, and thereby both concealed and intensified the political crisis brought about by the critique of the Enlightenment philosophers. ${ }^{110}$ In the 1960s and 1970s, Koselleck's repeatedly invoked the "makeability [Machbarkeit] of history" "111 together with its "producability,"112 "availability,"113 and "plannability." 114 The illusory makeability of history also manifested in concepts: since the saddle time, political and social concepts increasingly condensed future expectations and relied on utopian philosophy of history, oscillating between abstract inevitability and human makeability. "Revolution' thus became something "plannable," yet "autonomous,"115 and "progress' was equally "plannable" or "producible," 116 that is, a human task, while simultaneously remaining historically inavoidable on a legitimatory level. These theoretical observations provided the fuel for Koselleck's empirical explorations on concepts, and Freyer arguably equipped Koselleck with a critical tool, the argument concerning Machbarkeit.

Third, another aspect of ideological planning was its increased scale in the Cold War context. The spaces for which plans were made, Freyer argued, had expanded into continents or even the whole planet, which had turned the globe into a single "unified force field." 117 Yet due to the underlying tensions, the political unity of the world was still illusionary despite the

\footnotetext{
${ }^{107}$ Freyer, Theorie, 249, 250, 256.

${ }^{108}$ Hans Herrschaft und Planung: Zwei Grundbegriffe der politischen Ethik [1933], in Herrschaft, Planung und Technik: Aufsätze zur politischen Soziologie, ed. Elfriede Üner, (Weinheim: VCH, 1987), 17-43.

${ }^{109}$ Freyer, Theorie, 63-64, 69.

${ }^{110}$ Koselleck, Kritik, 8, 108, 111-115.

${ }^{111}$ Reinhart Koselleck, "Historia Magistra Vitae: Über die Auflösung des Topos im Horizont neuzeitlich bewegter Geschichte," [1967], in VZ, 61; Koselleck, "Über die Verfügbarkeit der Geschichte," [1977], in VZ, $261,270$.

112 Koselleck, "Historia," 62.

${ }^{113}$ Koselleck, "Verfügbarkeit."

${ }^{114}$ Ibid., 274.

${ }^{115}$ Reinhart Koselleck, sections I and IV-VII in "Revolution, Rebellion, Aufruhr, Bürgerkrieg," in GG, Band 5: Pro-Soz (Stuttgart: Klett-Cotta, 1984), 751.

${ }^{116}$ Koselleck, "Fortschritt," 403.

${ }^{117}$ Freyer, Theorie, 70, 250.
} 
liberal doctrine of progress and the Marxian ideology of planning, and the world was a "political force field ... loaded with enormous tensions." ${ }^{118}$ The world unity proposed by the philosophy of history had been attained only in the weak sense of technology, war, and political conflicts gaining global dimensions. This perspective derived from Weltgeschichte Europas, which argued more broadly that the problems of the contemporary world resulted from the spreading of European impulses throughout the world in the form of the "worldhistory of Europe." Freyer's book, which profoundly impressed Conze and Brunner ${ }^{119}$, also sparked Koselleck's interest in the question of a single world history. In 1950, Koselleck wrote a review of Freyer's Weltgeschichte Europas together with Karl Jaspers's Vom Ursprung und Ziel der Geschichte ${ }^{120}$, and in a 1953 letter to Schmitt, Koselleck lauded Freyer's book in the context of sketching an alternative ontology of history to counter Meineckean historicism, as pointed out by Olsen. ${ }^{121}$ Freyer's volume particularly taught Koselleck to read world history as reflecting European political impulses, as evinced by the very first sentence of Kritik und Krise: "The contemporary world crisis, defined through the polar tension of the world powers of America and Russia, is -- historically speaking -- the result of European history. European history has expanded into world history and becomes fulfilled in this world history insofar as it has brought the whole world into a condition of a permanent crisis. “122 Koselleck did not attribute the idea to Freyer, whose Europe book he cited some pages later in a rather marginal context. ${ }^{123}$ The point, however, reappeared reformulated in Koselleck's 1975 entry on "history." Since WW2, the stage of "round world history" had been reached and "centers of action" disseminated "pluralistically upon the Earth from Europe." ${ }^{, 24}$ When the aspirations for genuinely universal history ran aground with modern historicism, they remained what they had always been - the "world-history of Europe," Koselleck now noted with explicit reference to Freyer's volume. It was only in the twentieth century, he added, that this European world-history "began to change over to 'world-history itself"," whereby the "horizon of expectations created with the concept ['history'] by the eighteenth century" was "transformed, but not yet transcended." 25 The remark alluded to Freyer's point that a de facto universality of world history had been achieved in modernity, but, alas, only through the universalizing tendency of technology and its purest manifestation, the war machinery, rather than by any apotheosis of civilization and humanity as forecast by the philosophy of history.

Fourth, we must note that already Freyer traced the contemporary problem to the Enlightenment philosophy of history, posited a novel orientation to historical time therein, and described this as a direct consequence of political planning, thus preparing the ground for Koselleck's theory of the temporalization of history and concepts in modernity. The future first "broke into history" in Christian eschatology, but only its secularized successor, the doctrine of civilization, reason, and progress, turned the transcendental temporal scheme into a matter of immanent human activity. ${ }^{126}$ Rather than valuing the contemporary moment as a product of the past and maintaining its openness toward the future, the progress-oriented

\footnotetext{
${ }^{118}$ Ibid., 72, 252.

${ }^{119}$ Conze, [Review of Weltgeschichte Europas]; Brunner, "Problem einer europäischen Sozialgeschichte."

${ }^{120}$ Reinhart Koselleck, [review of Hans Freyer, Weltgeschichte Europas and Karl Jaspers, Vom Ursprung und Ziel der Geschichte], DLA Marbach, A: Koselleck, Konvolut: Texte und Notizen zu Heidegger, Jünger und Burckhardt.

${ }^{121}$ Olsen, History, 64, 94n72.

${ }^{122}$ Koselleck, Kritik, 1.

${ }^{123}$ Ibid., 13, 158n8.

${ }^{124}$ Reinhart Koselleck, sections I, V, VI and VII in "Geschichte, Historie," in GG, Band 2: E-G (Stuttgart: Klett, 1975), 716.

${ }^{125}$ Ibid., 690-691.

${ }^{126}$ Freyer, Theorie, 209-210.
} 
doctrines made it an "eye of the needle" through which history had to pass; the degree to which future progress had already been attained became a criterion for the present, and the human beings hereby "oriented themselves toward historical time" and found a proper place "between the past and the future."127 For Freyer, this was a consequence of history having become perfectable by human planning, and the new temporality had unmistakable political underpinnings. Only those in control of the present could "force the bottlenecks through which all innovation had to go" 128 , although philosophy of history served justificatory ends by disguising genuine political liabilities as historical inevitability. Obviously, Koselleck's interpretation of the emergence of a fully temporal history in early modernity is not reducible to Freyer's observations, yet we should not overlook how Freyer forged the link between planning and the new temporality and foreshadowed Koselleck's theorem.

Fifth, already Freyer noted the conceptual ramifications of the new orientation to historical time through planning. On account of their all-encompassing philosophy of history, the Enlightenment philosophers, Freyer posited, could use "vague general concepts" like "humanity, civilization, natural law, or progress" and still communicate something tangible ${ }^{129}$, and particularly the hovering between the inevitability of secularized eschatology and active human makeability "overdetermined" the notion of progress as used since the eighteenth century by early socialists, positivists, young Hegelians, liberals, and technocrats. ${ }^{130}$ The concept of 'progress' was thus general, but its uses were particular and linked with concrete acts of planning. Progress became a "flag" that each party "snatched" from other parties' hands, claiming that they, rather than their rivals, represented genuine progress. ${ }^{131}$ The new temporality thus not only situated the humankind between past and future, but also gave rise to novel vocabulary that could be utilized to direct the transition -and quarreled over.

In his post-war leaflet on political basic concepts, Freyer generalized this perspective into the idea that political concepts were "flags" capable of uniting people, moving political history, and, rather than only summarizing the movements retrospectively, also "showing them the way" in "bold anticipation [Vorgriff]."132 In being used for various political projects, political concepts attained different meaning and became weapons against political adversaries, but also means of disguising one's genuine interests, and concepts were the more capable of fulfilling this function the more ambiguous they had become -- a passage Koselleck forcefully underlined in his exemplar. ${ }^{133}$ These observations suggest that also Freyer had a doctrine of political concepts in the postwar era, comparable to, and possibly influenced by, that of Schmitt, which also shaped Koselleck's corresponding view of concepts. ${ }^{134}$ Like Koselleck's, also Freyer's view arose by generalization of the arguments regarding Enlightenment, underscored the role of concepts in guiding history, and depicted concepts as reloadable carriers of political energies. Rather than Schmitt's more openly partisan "politics of concepts," 135 Freyer's postwar view was closer to the constructive strand in Koselleck's theorizing insofar as Freyer noted that analyzing political concepts historically could not "reconcile political battle," but nevertheless "detoxify it." ${ }^{136}$ Koselleck has

\footnotetext{
${ }^{127}$ Ibid., 73-76.

128 Ibid., 64.

${ }^{129}$ Freyer, Weltgeschichte, II, 875.

${ }^{130}$ Freyer, Theorie, 210-211.

131 Ibid., 77.

${ }^{132}$ Hans Freyer, Politische Grundbegriffe: Demokratie, Liberalismus, Sozialismus, Konservatismus an ihrem Ursprung aufgesucht (Wiesbaden: Kesselring, 1951), 3-5.

${ }^{133}$ Ibid., 6.

${ }^{134}$ Pankakoski, "Conflict."

${ }^{135}$ Mehring, "Begriffssoziologie," 44-47.

${ }^{136}$ Freyer, Politische Grundbegriffe, 8.
} 
annotated the passage with a line in the margin of his exemplar, and Freyer's moderate approach may have contributed to his reformulation of the political aspect of Begriffsgeschichte.

There are thus extensive parallels between Freyer and Koselleck regarding the plurality and open-endedness of history, the criticism of history's plannability, the idea of world history as widened European history, a new temporal horizon in the eighteenth century, and the conceptual ramifications thereof. Rather than reducing these links into a set of one-way "influences" from Freyer exclusively, however, this is a case of a more complex dynamics of recycling. Brunner, for instance, also adopted the criticism of the philosophy of history (probably influenced by Freyer, yet also relying on Löwith) ${ }^{137}$ as well as the interpretation of the global situation as European problems writ large. ${ }^{138}$ Many of the above themes -- such as unity vs. plurality of history, criticism of the philosophy of history, or the world crisis as a result of early-modern political conflicts writ large -- were also Schmittian themes, and Schmitt, who admired Freyer ${ }^{139}$, may have served as an intermediary, while Freyer also occasionally adopted ideas from Schmitt. Neither did, Koselleck develop the ideas of older scholars single-handedly, but in horizontal interaction with intellectual peers like Hanno Kesting and Nicolaus Sombart, both of whom also knew Freyer's work. ${ }^{140}$ All of this underlines the collective nature of German postwar cultural debates. While the Koselleck/Freyer nexus should thus not be read reductively, the vast parallels, supported by Koselleck's occasional references to Freyer as well as his documented direct engagement with Freyers books, however, warrant the thesis of Freyer's formative role as regards the historical-political underpinnings of Koselleckian Begriffsgeschichte. Already in Freyer, the planning, makeability, and unity of history, as opposed to its openness and plurality, were all inherently linked with the new temporality and the concomitant directability of history with concepts. Koselleck decisively turned the setting around by perceiving matters from the viewpoint of concepts, eventually formulating his classical thesis on the saddle time - a period during which concepts, like history in general, were temporalized and gained novel meanings.

\section{Epochal thresholds and the Sattelzeit}

The very term and metaphor of "saddle time" has a complex history of its own, involving Freyer's ideas of 'cesura' and 'epochal threshold.' In a late interview, Koselleck denied that the Sattelzeit concept was inspired by Jaspers's notion of the "the axial age," but he more or less glossed over the interviewer's suggestion of a link with how Schmitt and Freyer spoke of a structural "rupture." ${ }^{141}$ Rather than acknowledging a connection to Freyer's work, Koselleck repeatedly cast Sattelzeit as a spontaneously invented and humorous catchword for a grant application, a term only later assuming a life of its own. He also lamented that the term was ambiguous and misleading because of its inherent metaphoricity. ${ }^{142}$

\footnotetext{
${ }^{137}$ Otto Brunner, “Abendländisches Geschichtsdenken,” [1954], in NW, 168-193.

${ }^{138}$ Brunner ("Inneres Gefüge," 320-321) posited that when European impulses were disseminated throughout the globe, "the Earth turned into a unified field of tensions [einheitliches Spannungsfeld]."

${ }^{139}$ See Carl Schmitt, "Drei Stufen historischer Sinngebung," Universitas 5 (1950), 930, and "Die andere HegelLinie," Christ und Welt 10, no. 30 (1957), 2. For the Freyer/Schmitt relation, van Laak, Gespräche, 97-99.

${ }^{140}$ On the relationships between Koselleck, Kesting, Sombart, and Roman Schnur, see Muller, Dangerous Mind, 104-115. For instance Kesting (Geschichtsphilosophie und Weltbürgerkrieg: Deutungen der Geschichte von der Französischen Revolution bis zum Ost-West-Konflikt [Heidelberg: Carl Winter, 1959], 296) commented on Freyer's notion of the "makeability" of history.

${ }^{141}$ Reinhart Koselleck in "Begriffsgeschichte, Sozialgeschichte, begriffene Geschichte: Reinhart Koselleck im Gespräch mit Christoph Dipper,” Neue Politische Literatur, 43 (1998), 194-195.

${ }^{142}$ Reinhart Koselleck, “A Response to Comments on the Geschichtliche Grundbegriffe," in The Meaning of
} 
Indeed, the metaphorical aspects have often been misunderstood: despite Koselleck's diffuse equine interests, the saddle time thesis is only marginally related to horses and horse saddles, while its primary meaning is geological and geographical. "Saddle" (Sattel, Bergsattel) is also a geological term referring to a point of passage between two mountains or the lowest point on a mountain ridge between two peaks, where it is the easiest to go across the mountain, from one valley to another. ${ }^{143}$ Spatially, the saddle area is a gateway to another space, yet simultaneously an obstacle to be overcome by exertion; in temporal terms, it signifies a transition phase with duration. The saddle metaphor thus rest upon a wider journey metaphor with a narrative structure and rich ramifications, including, importantly, an implied visual metaphor: whilst standing on the highest point on the route, i.e. the saddle point, one can see both the route one has already traveled and what still lies ahead.

Koselleck himself notes the alpine and visual layer of meaning in a late commentary: "One of the meanings of Sattel refers to horses, to the equestrian world, and another refers to the situation experienced when one climbs to the top of a mountain and from there can contemplate a larger view."144 The visual aspect is crucial for Koselleck's use of the metaphor: the saddle time is a transition period during which the pre-modern meanings of European social and political concepts were still accessible to anyone - and the future foreseeable. After the passage to the other side of the saddle, however, we moderns can no longer understand ("see") the meanings of pre-modern concepts directly, and future expectation have also surpassed any contemporary experience. The saddle time is thus simultaneously, first, a spatial metaphor implying a spatial extension like that in a landscape; second, a journey metaphor implying temporal duration and direction; third, a geological and alpine metaphor implying the tediousness of climbing; and, fourth, a visual metaphor implying seeing widely and to two directions whilst on top of the saddle.

Scholars have correctly identified many of the connotations of the saddle time metaphor. Particularly Jordheim notes both the spatial and visual aspects in Koselleck's image and makes two intriguing suggestions regarding the origin of the image: he first, refers to Husserl's idea of the contemporary moment as an extended field, continuity, or a saddle, and, second, cites William James's note on the contemporary moment as a "saddle-back, with a certain breadth of its own on which we sit perched and from which we look in two directions into time." ${ }^{145}$ Further, some scholars have traced the term to Brunner's influence on Koselleck $^{146}$-- justly, given Brunner's non-metaphorical summary of the key idea in 1949: "Words like 'state', 'society', 'nation', 'people', 'economy', 'family', 'culture', or 'civilization -- so self-evident to us -- received the meanings that we attach to them only since the eighteenth century[.] ... The European world of nobility relied on other concepts ... that we have to cumbersomely paraphrase if we wish to really comprehend their meaning." 147 The gist

Historical Terms and Concepts: New Studies on Begriffsgeschichte, ed. Hartmut Lehmann \& Melvin Richter (Washington: German Historical Institute, 1996), 69.

${ }^{143}$ This use is noted in Stefan Jordan, "Die Sattelzeit - eine Epoche für die Theologiegeschichte?" Schweizerische Zeitschrift für Religions- und Kulturgeschichte 105 (2011), 530.

${ }^{144}$ Koselleck in Javiér Fernández Sebastián and Juan Francisco Fuentes, "Conceptual, Memory, and Identity: An Interview with Reinhart Koselleck," Contributions to the History of Concepts 2, no. 1 (2006), 120-121.

${ }^{145}$ William James, The Principles of Psychology, cited in Helge Jordheim, “'Unzählbar viele Zeiten': Die

Sattelzeit im Spiegel der Gleichzeitigkeit des Ungleichzeitigen,"in Begriffene Geschichte: Beiträge zum Werk Reinhart Kosellecks, ed. Hans Joas and Peter Vogt (Frankfurt am Main: Suhrkamp, 2011), 454-455. Husserl may have got the idea from James, as suggested in Lilian Alweiss, The World Unclaimed: A Challenge of Heidegger's Critique of Husserl (Athens, OH: Ohio University Press, 2003), $191 n 37$.

${ }^{146}$ James Van Horn Melton, "Otto Brunner and the Ideological Origins of Begriffsgeschichte," In The Meaning of Historical Terms and Concepts: New Studies on Begriffsgeschichte, ed. Hartmut Lehmann and Melvin Richter (Washington: German Historical Institute, 1996), 32.

${ }^{147}$ Otto Brunner, Adeliges Landleben und Europäischer Geist: Leben und Werk Wolf Helmhards von Hohberg, 1612-1688 (Salzburg: Müller, 1949), 61. 
of the saddle time thesis can thus be found in Brunner, who also spoke of "wide transition areas" between epochs ${ }^{148}$, thereby representing temporal transitions in spatial terms. Further, Müller and Schmieder have recently suggested the historian Richard Koebner as a source of inspiration for the thesis, although not the metaphor. ${ }^{149}$ The core idea may have come partially from Brunner or Koebner, and, in principle, Koselleck may have been familiar with Husserl's and/or James's formulations; yet it seems more likely that Koselleck's framing of the saddle time and the associated imagery were inspired by Freyer's theorizing of "cesura" and "threshold" in Weltgeschichte Europas (1948), Theorie des gegenwärtigen Zeitalters (1955) and Schwelle der Zeiten (1965).

In the last volume, Freyer used the image of overstepping a threshold as a metaphor for the transition to the industrial society - a process of adaptation, which in his view was still ongoing. In substantial terms, crossing a threshold referred to a period of transition to a new epoch and the associated unintentional macro-level processes, but Freyer described this a transition in spatial terms as a passage in alpine landscape. In this argumentative context, Freyer describes Schwelle metaphorically as follows:

"A threshold ... [is] the intermediary landscape [Zwischengelände] between two territories, the mountain pass $[\mathrm{Pa} \beta]$ between two opposed drainage bases, a watershed and a weather divide, a barrier and simultaneously a bridge. On this side and on the other side of it one finds oneself on different niveau, perhaps even in another climate. To get from one to another, we must dare with the threshold, manage with it, and overcome it." 150

Freyer had, however, prepared the image by speaking earlier of a cesura (break, interruption, pause), which he linked intimately with epochal shifts. Four aspects of the Schwelle/Zäsur metaphor are crucial to note here in order to show the link with Koselleck's saddle time thesis. First, Freyer's threshold was simultaneously an obstacle to be overcome and a bridge to another world, comparable to a mountain pass. This layer of meanings brings Freyer's Schwelle very close to Koselleck's Sattel, which in geological language referred precisely to a lowest point in a mountain ridge through which transition to the other side was possible. Earlier Freyer had repeatedly spoken of European history being forced through a "bottle neck" or "choke point" $(\text { Engpa } \beta)^{151}$, which carries similar alpine connotations. Now he proposed that the epochal threshold (epochale Schwelle) led to "a new life-world" "152 and that, rather than the last phase of civilization, the industrial society was a "threshold into a new world situation" (die Schwelle zu einer neuen Weltsituation) ${ }^{153}$, thus molding the threshold as a point of passage. The terms Schwelle and Sattel were not only semantically nearly synonymous in geological parlance but also functionally equivalent in their usage.

Second, the transition across the threshold had a temporal extension. The shift to the industrial society at the turn of the eighteenth century was a "world-historical cesura" (eine weltgeschichtliche Zäsur) comparable only to the shift to sedentism in the Neolithic period ${ }^{154}$, a "cesura" with "an epochal character," 155 and a "cultural threshold" (Kulturschwelle). ${ }^{156}$ This transition had "an epochal character" in the original Greek sense of epokhe: in such turning points, history comes to a "pause" or "abeyance" (Schwebezustand) and "lingers [sich

\footnotetext{
${ }^{148}$ Brunner, "Forschungsaufgaben," 341.

${ }^{149}$ Müller \& Schmieder, Begriffsgeschichte, 265.

${ }^{150}$ Freyer, Schwelle, 12.

${ }^{151}$ Freyer, Weltgeschichte, II, 665, 667, 673.

${ }^{152}$ Freyer, Schwelle, 169.

${ }^{153}$ Hans Freyer, "Die deutsche Stadt: Geschichte und Gegenwart," in Entwicklungsgesetze der Stadt: Vorträge und Bereichte (Cologne: Westdeutscher Verlag, 1963), 11.

${ }^{154}$ Freyer, Theorie, 81 . Koselleck has underlined the term "weltgeschichtliche Zäsur" in his exemplar.

155 Ibid., 242.

${ }^{156}$ Freyer, "deutsche Stadt," 11.
} 
aufhalten] in the epochs before crossing them," whereas the chiliastic perspective within the modern belief in progress, misleadingly turned the present moment into a stadium (Stufe) to be "overstepped [überschritten] as soon as possible." ${ }^{157}$ Rather than being a momentary turn, Freyer's "cesura" thus denoted a period of transition: not only a turning point between eras but also an era in itself - both meanings being present in the etymology of "epoch." Similarly, the threshold began "subterraneously" and with "anticipations," but "no impatience or haste" could make the threshold "shorter" than it was, and one could easily be led to believe that one had already defeated the threshold when "the steep degrees" only began. ${ }^{158}$

Third, as the last words indicate, Freyer expressed the temporal extension of cesura metaphorically in spatial and physical terms, invoking the connotations of movement and traveling by foot in an alpine landscape. This aspect was enhanced by the fact that Freyer used 'cesura' (Zäsur) and 'threshold' (Schwelle) coextensively. In 1948, he ridiculed SaintSimon, Comte, and their contemporaries for having believed that the "way of humankind" led unavoidably from belligerent to industrial society and that the current era had already overstepped (überschritten) this threshold (Schwelle). ${ }^{159}$ In 1955 he noted how the humankind had currently not yet crossed (überschreiten) the threshold to the industrial society, but was only in the second phase of the "ascent," as Freyer noted in a passage constantly hovering between literal and metaphorical landscapes and incorporating Goethe's description of his ascent to the Italian city of Taormina and its the panoramic vistas. ${ }^{160}$

Fourth, the end of the journey was open precisely because the humanity had not yet reached the highest point, but was "in the middle of the threshold." 161 What lied "beyond the threshold" could only be "anticipated" or "expected," not "imagined" or "intended," let alone "made into a subject of a plan." 162 The threshold was thus also an obstacle that hindered humankind from preconceiving the future. Rather than a "way to a destination," the threshold was a "terrain" (Gelände) in which a way could possibly be found. ${ }^{163}$ If history was a road, it was one that only formed behind the traveller rather anything pre-set or foreseeable. ${ }^{164}$ Always "standing" at a certain "spot" on the "way" of history, which "leads to us and through us," we have no access to an "overview from a transcendental viewpoint," but can only see history as progress in that, and insofar as, we participate in that history. ${ }^{165}$ The threshold was thus also a visual obstacle which meant that there were no guarantees that the way provided by the threshold would not lead to a "dead end" or "a fall into an abyss." 166 For Freyer, the metaphor of the threshold was, thus, another way of relativizing the false certainty of the Enlightenment philosophy of history in favor of the openness of history.

The connotations are those of a mountain-climber moving uphill for better views across the threshold into the future, while for Koselleck the ridge rather blocked us from anymore comprehending the past meanings of concepts. Whereas Koselleck historicized the hike into a past transition in the meanings of concepts, Freyer's pessimistic diagnosis was that European modernity was still struggling to ascend - and would continue to do so, because the industrial society was anthropologically unsuitable for human beings and the process of adaptation still on-going. Neither is, however, Koselleck's "saddle" a mere one-time historical obstacle that blocked our view backwards into pre-modern times. "Saddle/threshold" is also metaphor for

\footnotetext{
${ }^{157}$ Freyer, Theorie, 217, 242.

${ }^{158}$ Freyer, Schwelle, 12, 168.

${ }^{159}$ Freyer, Weltgeschichte, II, 940.

${ }^{160}$ Freyer, Schwelle, 90-95, citation on page 94.

${ }^{161}$ Ibid., 223.

${ }^{162}$ Ibid., 324.

${ }^{163}$ Ibid., 299.

${ }^{164}$ Freyer, Weltgeschichte, I, 389.

165 Ibid., 390.

${ }^{166}$ Freyer, Schwelle, 322.
} 
our inability to see forward in time, which is a permanent condition in modernity, despite the misleading optimism at the height of the Enlightenment. The saddle time thesis is intimately linked with the makeability of history, for precisely the increased future-orientation and temporalization prompted the illusion of the human capability of steering history. The future could be -- and had to be -- planned precisely because it was unknown and undeducible from recurring forms. ${ }^{167}$ Simultaneously, however, the differentiation of present experiences from expectations and the concomitant acceleration of history made planning impossible. The abyss between the past and the future thus both motivated the ideological attempts to plan history and simultaneously grounded their inevitable failure. On this layer of meaning, the transition across the threshold is a mission never to be accomplished, for the saddle denotes precisely the point where our limited ability to foretell fails. Rather than only referring to a conceptual-historical thesis regarding the origins of European key concepts, Koselleck's saddle image thus also captures the idea more often expressed with the commonplace of the horizon always escaping us; it refers to a permanent metahistorical feature and a further condition for any "possible history." Koselleck never clarified this double meaning in the metaphor, but it becomes comprehensible when read in connection with Freyer's historical theory.

Considering the above parallels, it is unsurprising that Koselleck gradually amalgamated "saddle" and "threshold," eventually using them synonymously and interchangeably. In the programmatic Richtlinien text (1967), he only spoke of saddle time, horizons of experience (sic!), and the Janus face of the concepts of the transition era, without mentioning thresholds. ${ }^{168}$ Fives years later, in the introduction to the Geschichtliche Grundbegriffe, based on the Richtlinien article, he invoked "epochal threshold" (Epochenschwelle) and the "threshold [Schwelle] of our contemporary period" without, however, identifying either directly with the saddle time yet. ${ }^{169}$ This reinterpretation took place only in Koselleck's late work, but it was prepared in the 1970s, when Koselleck adopted 'epochal threshold' to his own vocabulary and used it in contexts involving large-scale epochal changes. For instance, he spoke of "crossing the epochal threshold [Epochenschwelle]"170 and a "road" leading "across the epochal threshold." 171 He saw the Reformation as an "epochal threshold"172, whereby the very concept of "Reformation' was a "threshold concept" or "epochal concept" (SchwellenbegrifflEpochenbegriff) ${ }^{173}$ Equally, he referred to the "epochal threshold" (epochale Schwelle) that "in the consciousness of those involved had been crossed [überschritten]" in the situation after the French Revolution, leading to the demarcation of the most modern period ('neueste Zeit') from modernity (Neuzeit). ${ }^{174} \mathrm{~A}$ "threshold that would lead the way for modernity" (eine für die Neuzeit wegweisende Schwelle) was also crossed (überschritten) in the late eighteenth century as the collective singular of history emerged. ${ }^{175}$ Koselleck spoke of the entire nineteenth century as a transition period (Übergangszeit) and an

\footnotetext{
${ }^{167}$ Koselleck, "Historia," 61.

${ }^{168}$ Koselleck, "Richtlinien," 82, 91.

${ }^{169}$ Reinhart Koselleck, "Einleitung [GG, Band 1],” XIV-XV.

${ }^{170}$ Reinhart Koselleck, "Einige Fragen an die Begriffsgeschichte von 'Krise,"” [1985/1986], in Begriffsgeschichten, 208.

${ }^{171}$ Koselleck, "Aufklärung und die Grenzen ihrer Toleranz," [1982], in Begriffsgeschichten, 348.

${ }^{172}$ Koselleck, "'Neuzeit,"” 309, 317.

${ }^{173}$ Ibid., 307-308.

${ }^{174}$ Ibid., 320, 337.

${ }^{175}$ Koselleck, "Geschichte," 667.
} 
"epochal threshold,"176 and, with reference to Brunner, of the "threshold [Schwelle] around 1800." $" 177$

Further, a "semantic threshold of experiences" (semantische Erfahrungsschwelle) was perceivable around the year 1780 -- yet, Koselleck argued, the perspective of temporal structures and non-synchronicity enabled scholars to transgress such context-boundedness in favor of historical comparisons across the saddle. ${ }^{178}$ While the visual obstacle of the saddle prevented relating with the past directly, the stratified underground structures continued uninterrupted and provided continuity under, rather than over, the mountain ridge, as it were. Interpreted in this way, the combined metaphor of geological layers, mountain saddles and visual obstacles is comprehensible and turns out to be instrumental in integrating several of Koselleck's ideas into a single framework. In the quasi-geological framework, the saddle time thesis is inherently interlinked with the theory of historical layers and non-synchronicity.

After having adopted the language of epochal thresholds to denote long-term and largescale transitions, the identification of threshold time (Schwellenzeit) with the saddle time (Sattelzeit) followed effortlessly: in his late essays, Koselleck used the two terms interchangeably. He for instance spoke of the "threshold time, which for Germany can be located between 1750 and $1850^{\prime \prime 179}$ and which is thus temporally coextensive with the saddle time. In a late debate with Pocock, Koselleck noted that perhaps "Schwellenzeit (threshold period) would have been a less ambiguous metaphor" than saddle time. ${ }^{180}$ Nowadays commentators use the two concepts synonymously, as evinced by Müller and Schmieder's reference to the "threshold and saddle time debate." 181

In addition to Freyer, Koselleck's terminological change may have been inspired by the philosopher Hans Blumenberg. On the page of one of the above instances, Koselleck referred to Blumenberg's Legitimität der Neuzeit, one volume of which was entitled 'Aspects of the Epochal Threshold. ${ }^{182}$ The reference is pertinent, as Blumenberg was a theorist of epochal thresholds in his own right. ${ }^{183}$ Yet Koselleck seems to have acknowledged Freyer's role behind Blumenberg's similar endeavors. In an undated and unpublished sketch for a conference proposal, Koselleck first linked the term 'epochal threshold' (Epochenschwelle) to Blumenberg, but then credited Freyer for having brought the term to discussion in $1965 .{ }^{184}$ This is remarkable, because in his published texts Koselleck never explicitly referred to Freyer as regards thresholds, and, consequently, the link with Freyer has escaped scholar's attention. The link was, however, obvious to Koselleck's colleagues: in a 1987 volume edited by Koselleck and Reinhart Herzog, František Graus paid attention to how Freyer's 1965 book had emphasized the spatial dimensions of the threshold, and also Herzog noted how already Freyer tied the threshold metaphor to that of the horizon, thus further stressing that the threshold was linked with the visual aspect of seeing far and in a roundabout way suggesting

\footnotetext{
${ }^{176}$ Reinhart Koselleck, "Das 19. Jahrhundert -- eine Übergangszeit," [1978], in Vom Sinn und Unsinn der Geschichte: Aufsätze und Vorträge aus vier Jahrzehnten, ed. Carsten Dutt (Frankfurt am Main: Suhrkamp, 2010), [hereafter $S U G$ ] 134-136.

${ }^{177}$ Reinhart Koselleck, "Begriffsgeschichtliche Probleme der Verfassungsgeschichtsschreibung," [1981], in Begriffsgeschichten, 371 .

${ }^{178}$ Reinhart Koselleck, "Geschichte, Geschichten und formale Zeitstrukturen," [1973], in VZ, 131. See also Palonen, Entzauberung, 280.

${ }^{179}$ Koselleck in "Begriffsgeschichte, Sozialgeschichte, begriffene Geschichte," 195.

${ }^{180}$ Koselleck, "Response," 69.

${ }^{181}$ Müller \& Schmieder, Begriffsgeschichte, 277.

${ }^{182}$ Koselleck, "'Neuzeit," $317 \mathrm{n} 41$.

${ }^{183}$ For comparisons between Blumenberg, Freyer, and Kuhn, see Severin Müller, "Paradigmenwechsel und Epochenwandel: Zur Struktur wissenschaftshistorischer und geschichtlicher Mobilität bei Thomas S. Kuhn, Hans Blumenberg und Hans Freyer," Saeculum: Jahrbuch für Universalgeschichte 32, no. 1 (1981), 1-30.

${ }^{184}$ Reinhart Koselleck, "Projektskizze zur Poetik und Hermeneutik XII,” DLA Marbach, A: Blumenberg, Jauss, Hans Robert / Blumenberg, Hans 1980--1986.
} 
a connection to Koselleck's Sattelzeit thesis. ${ }^{185}$ In his essay on the eighteenth century as the beginning of modernity, published in the same volume, Koselleck, however, neither commented on saddle time directly nor mentioned Freyer or Blumenberg, only stating vaguely that "to find a compromise between chronological milestones and structural determinations of depth, the expression 'epochal threshold' [Epochenschwelle] has gained currency in Germany."186

Koselleck repeatedly framed Sattelzeit as a spontaneous invention. The available evidence suggests that he did in fact coin the term, yet not without precedents that guided the formation and actual use of the concept, including Freyer's 'threshold' and 'cesura.' The core idea that the term covered, had also been expressed with a different wording by Brunner, whose perceptions on the transition between the eighteenth and the nineteenth centuries were heavily indebted to Freyer. Further, Koselleck certainly did not invent the rich imagery associated with the Sattelzeit -- including geological, alpine, and volcanic connotations as well as those of a journey across a mountain range, spatial-temporal extension, and seeing far. This material had accumulated in Western historiography since Herodotus, but had been authoritatively encapsulated in Koselleck's time by Freyer. Koselleck's exemplar of Schwelle der Zeiten is not available, yet we can safely assume that he was familiar with the volume he referred to, and Freyer's theorizing of threshold seems to have guided Koselleck's use of the metaphors. Freyer, possibly together with Blumenberg, catalyzed Koselleck's later reinterpretation of saddle time as synonymous with threshold time, and in the unpublished note, Koselleck did in fact credit Freyer for the term 'epochal threshold,' which he elsewhere only attributed to Blumenberg.

\section{Conclusions}

Rather than an analyst of trans-historical and abstract concepts, Freyer was a "recovering Hegelian," proposing politically oriented historicism extendable onto concepts. His role in the genesis of German historical semantics and Begriffsgeschichte has so far been underestimated. As shown above, Freyer was not only a major background figure in Brunner's and Conze's history of structures, but his categories also shaped Begriffsgeschichte and guided its way of asking questions. Before 1945, Brunner's engagement with Freyer's methodological ideas was also supported by vast parallels in their ideological aims, as evinced by their criticism of the industrial society and their representation of Volk as a permanent substructure despite the historically satiated nature of other key concepts. Brunner abandoned such ideological imbalance only after WW2.

His younger colleagues Conze and Koselleck, by contrast, primarily relied on Freyer's postwar re-renderings of the political dynamics of history, and encountered his methodological terminology, together with its supportive imagery, in deradicalized form. Freyer's pre-war affirmative emphasis on the continued potential for political upheavals was absent in their model of layered history, while many theoretical-methodological points remained, such as the political nature of stratification, the multilayeredness of history, or the presence of the past through the contemporaneity of the non-contemporaneous. This shift corresponds to the way Koselleck, in Mehring's estimation, renounced the active Schmittian "politics of concepts" in favor of a more historically oriented approach. Despite this successful distanciation from political radicalism, even Koselleck's late work on temporal

\footnotetext{
${ }^{185}$ František Graus, "Epochenbewusstsein im Spätmittelalter und Probleme der Periodisierung," in Epochenschwelle und Epochenbewusstsein, ed. Reinhart Herzog \& Reinhart Koselleck (München: Fink, 1987), 153n1; Reinhart Herzog, “Epochenerlebnis 'Revolution' und Epochenbewusstsein 'Spätantike': Zur Genese einer historischen Epoche bei Chateaubriand," in ibid., 195n2.

${ }^{186}$ Reinhart Koselleck, "Das Achtzehnte Jahrhundert als Beginn der Neuzeit,” in ibid., 270.
} 
layers and repetitive structures, nevertheless, had "a conservative appeal.", ${ }^{\text {"187 }}$ My analysis, however, suggests that any remaining, moderately conservative emphasis in Koselleck's theory of historical layers, is of Freyerian, not Schmittian, origins, and comes supported by the Freyerian geological imagery recycled also by Conze.

The comparison with Freyer illuminates the interrelations between the key concepts in Koselleck's theory of history. Jordheim has underscored the close relationship between the saddle time thesis, the eighteenth-century spatial extension of European history into world history, and the Gleichzeitigkeit theorem within Koselleck's oeuvre. ${ }^{188}$ Indeed, in the global field of historical action - opening up during the saddle time and largely as a consequence of political aspirations -, experiences of the simultaneous presence of different historical layers became more frequent and intense, turning into a basic experience of modernity. Freyer, however, had not only suggested the ideas of the threshold into industrial society, the globalization of European political impulses in world history, and the presence of historical layers in the contemporary moment, but he also provided a single theoretical framework in which all these pieces fell into place. The overall image forming in the Koselleckian puzzle, too, is overwhelmingly Freyerian, although also encompassing fragments from other images. This is vividly emblematized by the fact that the dust jacket of the second edition of Weltgeschichte Europas reproduces Albrecht Altdorfer's Alexanderschlacht -- the sixteenthcentury painting which, probably coincidentally, sparked Koselleck's reflections on historical time in the opening essay of Vergangene Zukunft.

\footnotetext{
${ }^{187}$ Mehring, "Begriffssoziologie," 45.

188 Jordheim, “'Unzählbar viele Zeiten,"” 457, 463.
} 